DOI https://doi.org/10.36059/978-966-397-232-9-6

\title{
LINGUISTRAGMATICS OF A POLITICAL POSTER: INTERACTION STRATEGIES WITH ADDRESSES
}

\section{Kondratenko N. V.}

\section{INTRODUCTION}

Modern pre-election discourse is characterized by the active use of new speech technologies of influence and the involvement of various genre forms in the process of political propaganda. Along with the newest genre formations, traditional ones are also used acquiring new features in the conditions of the information society and preserving their suggestive potential. Such genres include political poster, which at the beginning of the XXI century was transformed into various genre forms of outdoor advertising, including billboards, city lights, lightboxes, convection boards, backlights, prismatrons, firewalls and more. The sphere of distribution (street advertising), large size and presence of the image and the text part, the main purpose of which is to influence the addresses, unite all these genre manifestations of the poster. The latter characteristic distinguishes all genre varieties of posters as promotional products based on the synthesis of verbal and nonverbal information and provides visual perception by the addresses. Such diversity and influence of posters has enabled their active use in political campaigning: posters as elements of election discourse have been actively presented in the election campaigns of recent years, demonstrating the linguo-pragmatic potential of polycode texts. The specifics of the functioning of political posters are determined by the strategic parameters of political discourse, which determine the effective interaction with potential addresses.

The purpose of the study is to identify the main strategies of interaction with the addresses in political posters as polycode manifestations of Ukrainian political discourse. The purpose determined the following tasks: to define the concept of political discourse and its variety - political election discourse; to identify the features of the political poster as a genre of election discourse; to characterize and typologize the main communication strategies of influencing the addresses in political posters. The material for the analysis was the political posters presented in the Ukrainian election discourse in 2019-2020 during the presidential, parliamentary and regional election campaigns. A total of 355 posters were analyzed.

Scientific novelty of the study is due to the deepening of the polycode theory as the main manifestation of linguosemiotics of political discourse: clarification of the typology of speech genres of political discourse in terms of defining a political poster; substantiation of the concept of political 
linguosemiotics and conduction of a linguistic experiment to identify the influential potential of political posters of a polycode nature.

\section{Poster as a genre of political pre-election discourse}

Interpretation of political discourse as an institutional kind of discursive human activity is present in the works of many scholars (V. Karasyk, M. Makarov, K. Serazhym, O. Sheigal, etc.). Thus, L. Pavliuk claims that the basis for distinguishing types of discourses, including political ones, is "the usual thematic orientation, an indication of the range of life phenomena and related motives"1 All linguists agree with this as this variety is represented in typologies based on social, communicative, thematic and functional features. However, the basic features and characteristics of political discourse vary depending on the scientific concept.

O. Sheigal believes that all elements of "the field of politics are somehow mediated by discourse, reflected in discourse, realized through discourse: they either constitute the subject of communication (its reference aspect), or act as elements of a pragmatic context, including pragmatic presuppositions" ${ }^{2}$ L. Slavova believes that political discourse "can be defined as a set of all speech acts, as well as rules of public policy, which were formed in accordance with existing traditions and tested by experience" ${ }^{3}$ Thus, from the proposed definitions it can be concluded that when defining political discourse, the determining criterion is linguo-pragmatic, which takes into account the intentionality, specificity of speech acts and political speech genres. A. Chudinov insists on the presentation of typical features of the political communication in the form of antinomies, "contradictory trends, each of which fully reflects the essence of the object under study" According to A. Baranov, the increase in interest in the study of political texts can be explained by the following reasons: 1) the internal needs of linguistic theory, which at different times addressed different areas of the language system, 2) political aspects of studying political thinking, its relationship with political behavior, the need to develop methods of analysis of political texts, 3) social order, the desire to free political communication from manipulation of public consciousness 5 .

${ }^{1}$ Павлюк Л.С. Текст і комунікація: Основи дискурсного аналізу. Львів : ПАІС, 2009. С. 15.

${ }^{2}$ Шейгал Е.И. Семиотика политического дискурса. Москва : Гнозис, 2004. С. 24.

${ }^{3}$ Славова Л.Л. Мовна особистість лідера у дзеркалі політичної лінгвоперсонології: США - Україна. Житомир: Вид-во ЖДУ ім. І. Франка, 2012. С. 67.

4 Чудинов А.П. Современная политическая коммуникация. Екатеринбург : Уральский гос. пед. ун-т, 2009. С. 42.

${ }^{5}$ Баранов А.Н. Введение в прикладную лингвистику Москва : Эдиториал УРСС, 2001. C. 245. 
Pre-election political discourse is a complex communicative event and at the same time is a verbal design of this communicative event. It is characterized by certain communicative roles and composition of participants, differs in publicity and formality ${ }^{6}$. For the pre-election discourse, as well as for the general political one, the main concepts are "power" and "politician", but the center of gravity in the former is shifted to "struggle for power"7.

Pre-election discourse has all the features of political discourse and performs all its characteristic functions, but there is an essential feature that distinguishes it as an independent discourse within the political one - the fact that election discourse belongs to a certain communicative situation and has clear time constraints, i.e. it is implemented during the campaign period specified by law.

Researchers of pre-election discourse highlight another important feature thematic determinism ${ }^{8}$. While in other genres of political discourse the number and content are practically unlimited, in the election discourse they are focused on the activities of certain candidates or political associations - participants in the election campaign. The main task of the pre-election political discourse is to suggest to the addressees (voters, citizens) the need to carry out "politically correct" actions or assessments. Influence on the consciousness of the addressee can be carried out by various methods and is aimed at changing the initially existing in the individual picture of the political world by introducing into their mind certain thoughts, attitudes and / or guidelines.

O. Gaikova, considering the pre-election discourse as a genre of institutional communication, notes that it belongs to different types of discourse: institutional (political) and non-institutional (ritual and rhetorical) ones. The author "interprets the genre of pre-election discourse as a hybrid genre that has the characteristics of institutional, rhetorical and ritual communication. Pre-election discourse is a speech act which has the features of emotional attitude, appeal and motivation to action"”.

T. Golubeva calls the pre-election discourse "activity, the localization of which is the time and space of the election campaign, and the texts that arise as a result of this activity and actualize the socio-cultural context of

6 Халатян А.Б. Предвыборный дискурс. Политическая лингвистика. 2011. № 2. С. 182 .

7 Чудинов А.П. Современная политическая коммуникация. Екатеринбург : Уральский гос. пед. ун-т, 2009. С. 43.

${ }^{8}$ Гайкова О.В. Предвыборный дискурс как жанр политической коммуникации: на материале английского языка: дис. канд. филол. наук. Волгоград, 2003. С. 23.

${ }^{9}$ Там само. С. 32. 
communication"10 Among the main characteristics of the pre-election discourse, the researcher includes the desire to apologize (present in the favourable light of his candidate or party) and the focus on criticism, which is manifested in the discrediting of the opponent.

Pre-election discourse, as well as any other format of communication, due to cultural and situational norms ${ }^{11}$, is embodied in speech genres. Of course, the success of pre-election communication depends on a number of factors, among which an important role belongs to the communicative competence of the politician, which depends in particular on his ability to use different speech genres.

The definition of genres of political pre-election discourse is closely related to the typology of genres of political discourse in general. O. Bylinska, analyzing the propaganda political discourse, notes: "the typology of political discourse does not have fixed genre forms, which are realized as textual formations, as the syncretic nature of political texts determines the possibility of their application in all types of political discourse"12 The collective monograph of O. Bylinska, N. Kondratenko and L. Stryi presents a complex typology of speech genres of political discourse ${ }^{13}$. Thus, researchers have identified five groups of political genres: self-presentation, informational, ritual, propaganda and agonalargumentative ones. The genre of political poster is traditionally characterized as kind of printing products, which is focused mainly on emotional impact, so it should impress, intrigue, and arouse interest.

A poster is an important component of political communication, which allows communication between its participants. Social movements use political posters as a means of expression, for example during rallies, pickets and demonstrations. In addition, a poster is seen as a means of visual political communication, which acquires special significance during the political campaign $^{14}$.

A political poster is a "single work of art, a concise, prominent (usually coloured) image with a short text (usually on a large sheet of paper), made for

10 Голубева Т.М. Языковая манипуляция в предвыборном дискурсе: на материале американского варианта английского языка : автореф. дис. канд. филол. наук. Нижний Новгород, 2009. С. 10.

${ }^{11}$ Карасик В.И. Языковой круг: личность, концепты, дискурс. Москва : Гнозис, 2004. С. 108.

${ }^{12}$ Билінська О.С. Агітаційні жанри українського політичного дискурсу: сугестивний і лінгвопрагматичний аспекти. Дис. канд. філол. наук. Одеса, 2017. С. 39.

${ }^{13}$ Кондратенко Н.В., Стрій Л.І., Билінська О.С. Лінгвопрагматика політичного дискурсу: типологія мовленнєвих жанрів : монографія; за заг. ред. Н.В. Кондратенко. Одеса : Астропринт, 2019. 236 с.

14 Ирисханова О.К. Полимодальность в социокогнитивном освещении: семиотика плаката. Когнитивные исследования языка. 2012. № 11. С. 66. 
propaganda, advertising, informational or educational purposes" ${ }^{\prime 15}$ A. Altunyan notes that political text is characterized by a principled focus on the potential reader, listener ${ }^{16}$. Moreover, a function of a political text is completely determined by its pragmatic function. A political text does not exist for and by itself, which is theoretically possible for other types of texts. It is always a tool to influence a potential audience. In principle, all its methods must be decipherable, and all its meanings must be completely exhausted in the analysis of the direct word and the methods used by the author of the text.

For a political poster, "the illustration of a verbal text makes modifications to the process of its perception and the construction of its content"17. Considering this, we interpret the poster as a polycode text because in its perception only the visual channel of communication is used.

From the point of view of structural organization, the following types of political posters can be distinguished: posters that only have a verbal component; posters combining the image and the verbal component; posters containing only images ${ }^{18}$.

Posters of the first type (46\%), which contain text designed with the help of language signs, are not semiotically homogeneous because the information expressed verbally in the texts of this type always has a graphic design. Given this, in addition to the verbal code, they also have graphic and colour ones. The choice of font, the organization of verbal elements in the space of the poster belong to the graphic code, while the colour design of the text and background should be considered as a colour code. However, the main attention of addresses is paid to the verbal component. This type of minimization of the nonverbal component has dominated the political posters of the Ukrainian election discourse for the last two years. This is primarily a cost-effective means of presenting advertising as a necessity, but with minimal financial investment: the lack of bright printing such as photographs indicates the desire of political forces to assert themselves without spending extra money. In the context of the economic crisis in the country, such a strategy is quite justified: potential voters cannot blame politicians for spending unnecessary costs on advertising.

15 Магера Т.С. Текст политического плаката: лингвориторическое моделирование (на материале региональных предвыборных плакатов) : автореф. дис. канд. филол. наук. Барнаул, 2005. С. 15.

${ }^{16}$ Алтунян А.Г. Анализ политических текстов. Москва : Логос, 2006. С. 89.

${ }^{17}$ Ворошилова М.Б. Политический креолизованный текст: ключи к прочтению. Екатеринбург, 2013. С. 23.

18 Ситар Г.В., Галюк А.В. Політичний плакат: співвідношення вербального й візуального складників. Вісник студентського наукового товариства ДонНУ імені Василя Стуса. Вип. 12. Том 2. С. 220-222. 
Posters of the second type (38\%) are also semiotically complicated. The basic semiotic code of such posters is verbal, but a significant role belongs to graphic, colour and iconic codes, which are non-verbal. By iconic code we mean drawings, photographs and other graphic images incorporated into the text space of the poster. The use of photos of specific politicians is generally characteristic of the pre-election discourse: the slogan and the surname of the politician are presented against the background of the photographic image.

Posters of the third type, which contain only images and are devoid of the verbal component (16\%), are not widely used in election discourse. The absence of a verbal component indicates that information in this case recedes into the background, the main thing is the assertion of the presence of a party or a recognizable candidate in the electoral landscape. In this case, the image is still accompanied by text - it is either the name of a politician or a slogan. Due to this, posters of this type are also polycode in semiotic terms because they contain colour and graphic code.

However, most political posters do not belong to one of these types, but are an organic combination of all the components.

We also include their seriality in the specific features of a political poster. Seriality of political posters is a set of several texts designed to solve one practical problem, similar in content and having a significant formal similarity. It is important that each text included in the series is created and perceived as an element of the series, which contributes to the formation of new pragmatic guidelines. Seriality of posters reveals the mechanisms of influence in paradigmatic terms and forms the possibility of presenting the basic elements of form expression.

\section{Strategies of interaction with the addressee in political posters}

Among the current problems of linguopragmatics, a special place belongs to communicative strategies and communicative tactics. Modern linguists formulate definitions of communicative strategy in different ways: K. Sedov calls them "general pragmalinguistic principles of implementation of illocutionary content" " ; O. Selivanova believes that the strategy is "a component of the heuristic intentional program of planning discourse, its implementation and management in order to achieve a cooperative result, the effectiveness of information exchange and influence" ${ }^{20}$; T. Yanko notes that the strategy "consists in the choice of communicative intentions, in the distribution of quanta of information by communicative components and in the

${ }^{19}$ Седов К.Ф. Дискурс и личность: Эволюция коммуникативной компетенции. Москва : Лабиринт, 2004. С. 35.

20 Селіванова О.О. Сучасна лінгвістика: напрями та проблеми. Полтава : Довкілля-К, 2008. С. 607. 
choice of the order of communicative components in the sentence" ${ }^{21}$. According to O. Issers, communication is not a chaotic set of remarks and statements, but an orderly phenomenon so the strategy "covers the planning of the process of speech communication depending on the specific conditions of communication and personalities of communicators, as well as the implementation of this plan. In other words, speech strategy is a set of speech actions aimed at achieving a communicative goal",22.

Let us consider the main strategies of interaction with addresses, implemented in the genre of political poster.

1. Propaganda strategy presupposes the presence of an appeal in the form of a motivational sentence or verb forms of the present tense or infinitive, i.e. it is the realization of the main function of the pre-election discourse propaganda, e.g.: Think!,Think! (P. Poroshenko, 2019); Change! (Yulia Tymoshenko, 2019); Trust the deeds! (G. Trukhanov, 2020). At the verbal level, we record the use of imperatives: syntactic constructions with the imperative verb forms, e.g.: Choose NATO and the EU. Join (European Solidarity, 2019), Do NOT lose another 5 years! (Servant of the People party, 2019); present, e.g.: We stop the destruction of the country (Palchevsky's "Victory" Party, 2020); We know. We can. We act (Ukrainian strategy of V. Groysman, 2019); infinitive, e.g,: We have to act! (Yu. Tymoshenko, 2019).

At the non-verbal level, political posters that implement the propaganda strategy are not particularly different from the others. The focus here is on the text.

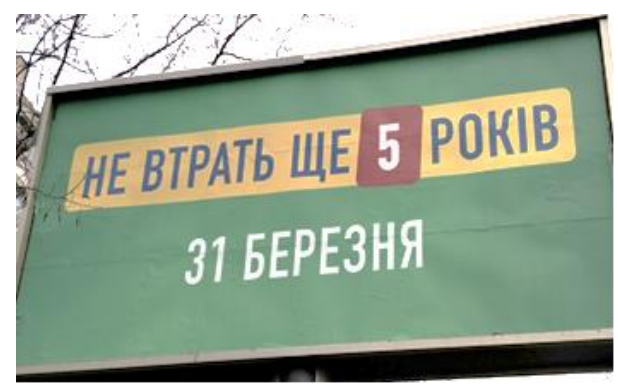

Iconic elements are mostly images of those politicians who call on the potential voters to support their political force on elections. To express the

21 Янко Т.Е. Коммуникативные стратегии русской речи. Москва : Языки славянской культуры, 2001. С. 38.

${ }^{22}$ Иссерс О.С. Коммуникативные стратегии и тактики русской речи. Москва : КомКнига, 2006. С. 54. 
propaganda strategy, the verbal components of political posters are mainly actualised, while non-verbal ones play a supporting role.

2. Argumentative strategy is aimed at explaining the political position of a particular entity to the voters. It is based on logical ways of reasoning deduction, induction, analogy. Mostly at the verbal level, there are statements that have a causal or explanatory nature. Similar to the propaganda strategy, in the argumentative one we observe the dominance of verbal components: argumentation is presented in political slogans, e.g.: Our goal is to build Europe in Ukraine (European Solidarity Party, 2019); Polite people in power - a decent life for people (A. Grytsenko, 2019); Spring is coming - we will plant! (in Ukrainian the word used is саджати which has the meaning of 'planting' and 'imprisoning' at the same time) (Servant of the People party, 2019); Land for Ukrainians, not foreigners (O. Lyashko's Radical Party, 2019); The local church is the key to independence (P. Poroshenko, 2019).

In such cases, the slogan is not declarative; it explains the political position of a particular candidate or party.

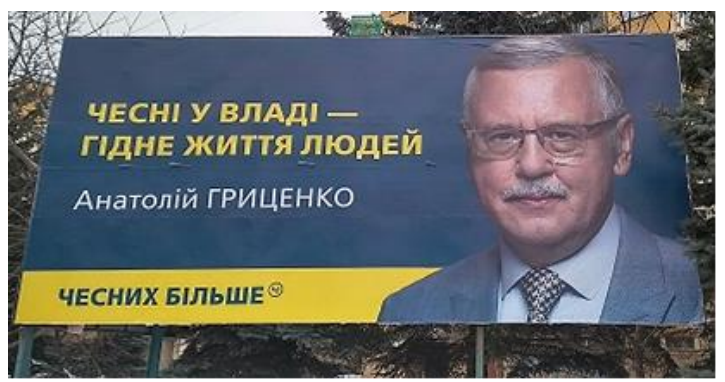

The above political poster contains argumentation presented by a particular politician's slogan.

Thus, the argumentative strategy is based on the provisions of the political program and involves the use of conceptual slogans. Under such conditions, the slogan becomes a core element of the political poster, and the image performs an auxiliary function.

3. Confrontation strategy involves criticizing political opponents during the election campaign: in this case, the political poster does not contain a positive description of the political entity being advertised, but the leveling of the image of its opponents. An important element of the confrontational strategy is the recognizability of political symbolism at the level of linguosemiotics: symbolic colours, characteristic graphic elements are used not for support, but for criticism. 
This includes the "adverse publicity" tactic, which is aimed at denying political advertising in general: a political force presents its position on the need for political advertising in the form of political posters, so we call this trick a tactic of paradox.

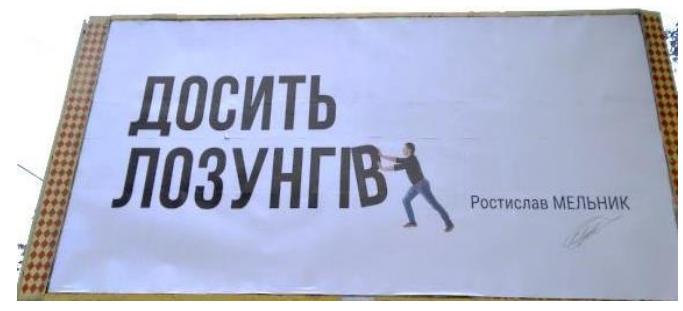

In this example, most of the political poster is occupied by the text "ENOUGH WITH THE SLOGANS", which is combined with the image of a little man pushing the last letter. However, on the right we see the surname and name of a politician Rostyslav Melnyk and his facsimile signature, which shows the internal contradiction between the appeal and the image.

4. Dialogic strategy is aimed at actualizing the pseudo-dialogic interaction between political agents: there is an appeal to the competitors' advertisement in the form of political posters. In view of this, the linguosemiotics of other political forces are used: colour, graphic elements, slogan structure, etc.

A striking example is the advertising with the slogan "You Think" without citing a political entity using the state colors of Ukraine as a kind of "replica-response" to the Poroshenko's political advertising of "Think!" The graphic highlighting of the letters "You" indicates a certain politician Yulia Tymoshenko, who is the only candidate for the presidency to have the letter standing for the corresponding sound in her name or surname. Here the dialogicity is realized mainly on the verbal level. Other elements have changed - the color and layout of the text, but the structure of the political poster with the words in the center remained unchanged. Such implicit advertising is manipulative because the absence of the name of a political 
force and the presence of a neutral slogan, on the one hand, allows to perceive the poster as social advertising, and, on the other hand, is the advertising of a particular politician.

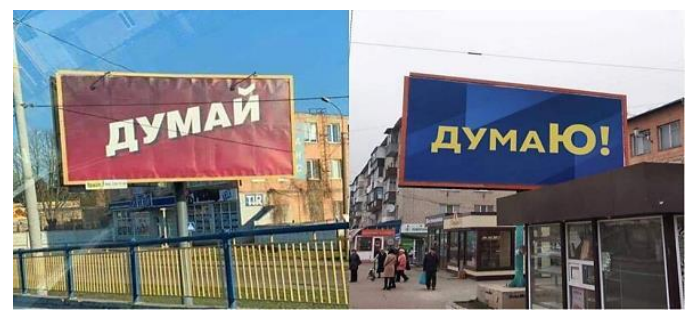

The strategy of dialogicity is implemented on a verbal-symbolic level as texts and graphic elements are used.

Prerequisite for the implementation of the dialogic strategy in a correlative advertising is the location: the ads should be placed next to each other or at a short distance so that addresses perceive them as elements of a single pre-election discourse.

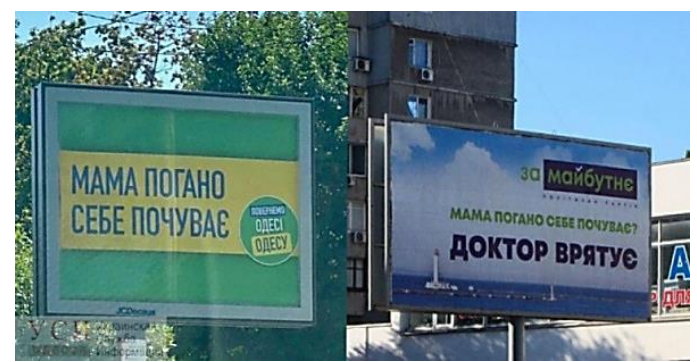

The illustration shows the successful placement of the advertisement of the party "For the Future" with the slogan "Mom feels bad? The Doctor Will Save" next to the advertisement of the Servant of the People party, whose slogan is the first part of the text represented on the second political poster. At the same time, advertisements of both parties appeared without a semantic connection, but "For the Future" used the unsuccessful slogan of their opponents. Although in the first case it was about the party as a whole, and in the second - about a specific political leader, the comparison made it possible to present a dialogue. 


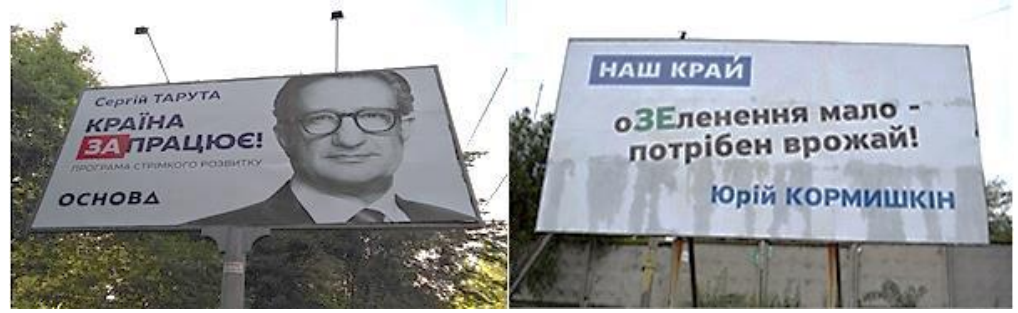

In this example, the political poster of the party "Osnova" of S. Taruta (elections to the Verkhovna Rada, 2019) contains a red box with the Ukrainian preposition " $3 \mathrm{a}$ ", which parodies a key verbal element of the party "Servant of the People" - the letter combination " $3 e$ ", which is also a part of President V. Zelensky's last name and transcribing of the English article "the", actively used in the political posters of this political force.

And the second political poster also appeals to the separation of " $3 \mathrm{e}$ ", criticizing opponents, but here the same graphic layout and semantics of color are used.

We observe the implementation of the dialogic strategy even within a single political poster: in this case, various elements that are part of the political posters of opposed political forces are graphically combined. In this case, the main political poster seems to ironize the original, using for its own purposes the symbols and text of competitors. The authors of the poster take into account the linguosemiotics of opponents, entering into a kind of dialogue with certain parts, including verbal one.

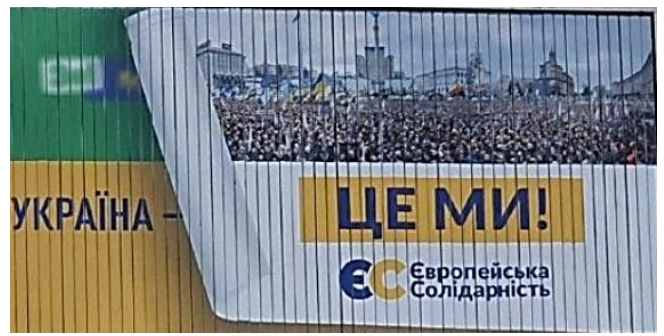

This example demonstrates the combination of two political posters, the Servant of the People party and the European Solidarity party, with the effect of overlapping two paper posters: as if on a political poster of the first political force, showing only the word "Ukraine" (The initial element of the slogan "Ukraine is you"), there is a pasted poster of the second party, also showing only part of the image and text. The visual combination of these two posters gives a new slogan: Ukraine is us (with the name of the party 
"European Solidarity"). Such an expression of dialogicity is an expression of the irony tactics.

5. Intimidation strategy is that at the visual and verbal levels, political posters present possible consequences for addresses of either the wrong (from the point of view of the authors of the advertisement) choice, or in general non-participation in the election. The second option shows political posters where the passivity of voters is represented as the reason that other people will make a choice, which will endanger people's freedom, health and life. Let's demonstrate this strategy on the example of Odessa advertising: If you do not come to the polls, polite people can come to you! This political poster is unusual on both verbal and non-verbal levels. First, it does not campaign for a specific political force or politician, but contains a call to participate in elections. The slogan of causal content, presented in the poster, contains tokens of different languages - Ukrainian and Russian. At the same time, the word "polite", graphically highlighted in black, is printed in Russian, which is a precedent statement (quote by Vladimir Putin) and indicates the situation with the annexation of Crimea by the Russian troops.

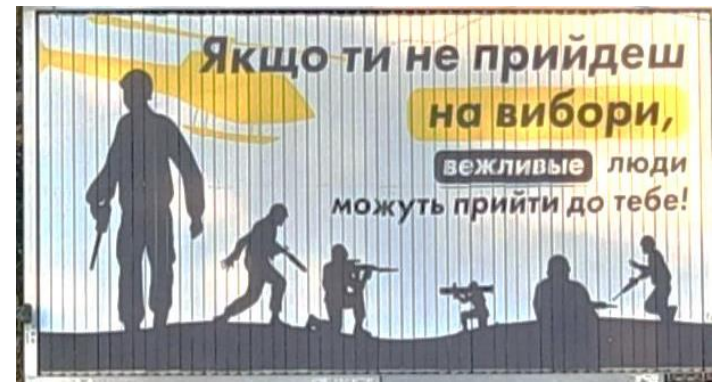

In this way, the analogy of "Odessa - Crimea" and the comparison with the events in Donbass are actualised in the minds of the addresses. The appeal to basic human needs here is based on the most important categories - human life and health. Iconic signs - graphic images of the silhouette type - in the lower part of the political poster aggravate the situation of danger described in the verbal part. Black graphic elements are figures of people in military uniform (helmets are visible) with weapons (submachine guns, rifles, grenade launchers). At the top of the poster, there is an image of a yellow helicopter. In general, white, black and yellow are used creating the effect of contrasting the achromatic image with colour.

The intimidation strategy is used through the comparison of the possible consequences of a bad political choice. Its realization is most vividly presented in a political poster, which is visually divided into two parts, each 
of which presents a photographic image of a certain building: on the left - a white Vorontsov lighthouse in Odessa against a clear blue sky and blue sea, and on the right - a destroyed tower of Donetsk airport. The text part duplicates presented images in the form of categorical statements: Odessa peace (italics of yellow color), Donetsk war (blurred letters of red color), between which the conjunction or is inserted. In our opinion, yellow here is a symbol of the sun, peace and tranquility, and red (especially since red letters are printed with the effect of drops falling down) - death, blood, pain and war. In the middle of the image, there is the main slogan of a motivating nature: "Choose yourself", i.e. the recipient must, making a choice during the vote, choose what he wants to see in his city - peace or war.

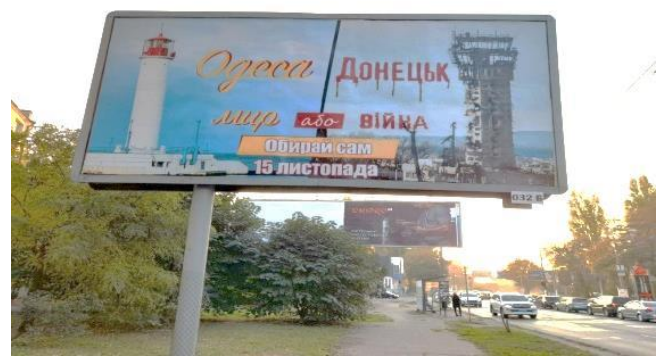

Here we observe a combination of an opposition (confrontation) strategy of with a strategy of intimidation.

6. Intertextual strategy involves the use of intertextual elements precedent phenomena, quotations, appeals to known historical events and more. First of all, this includes various quotations from the classics of Ukrainian literature, often without reference to the source: in this way, the authors of advertising indicate the attitude towards the addressees. Those of the addressees who decodes the source of the quotation, belongs to the circle of the chosen ones who understand the communicative intention of the authors.

Thus, in the 2020 elections, the party "For the future", appealing to the names of the pro-presidential party "Servant of the People" and the famous slogans "President is a Servant of the People" and "Deputy is a Servant of the People" built an election campaign based on the intertextual strategy. Political posters containing a quote from Ivan Franko (transformed in a way), in addition to the actual text, were made in the symbolic colours of the party, and the authorship of the quote was not specified. 


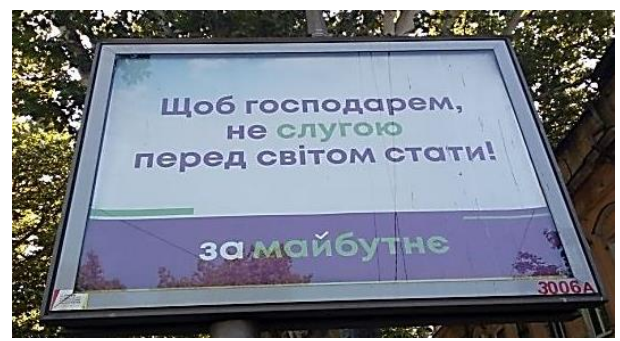

However, political posters also use quotes using the names and even images of their authors. For example, the poster has a picture of Ivan Franko, a quote and a name. In addition, it is stated why the quote "It's time for us to live for Ukraine" was chosen for political advertising.

7. Intriguing strategy is aimed at creating in the addresses a desire to get acquainted with the further advertising of a particular candidate or to find out who exactly is represented in the political posters that do not indicate a specific political force. This strategy is used only at the beginning of the election campaign to make addresses guess whom the advertisements are about. The first successful example of this strategy was tested in the 2010 presidential election in Yu. Tymoshenko's election billboards "She works". Since then, the intriguing strategy has been actively used in elections at various levels.

The appearance of political posters, the content of which is incomprehensible to the recipients, is the first sign of the use of the intriguing strategy. Thus, in Odessa in 2020, the intriguing strategy was presented in a number of political posters. Initially, political posters appeared with the slogan "Odessa needs a doctor", which had an implicit link to a certain subject, which was to be associated with the concept of "doctor". Potential voters were waiting to see who became the subject of the political advertising. There is a certain contradiction here, because in Ukrainian "doctor" is only the name of a scientific degree, so when the next stage of this advertisement was "Odessa needs Kalinchuk", who is a doctor by profession, the mistake of the authors of political posters became clear.

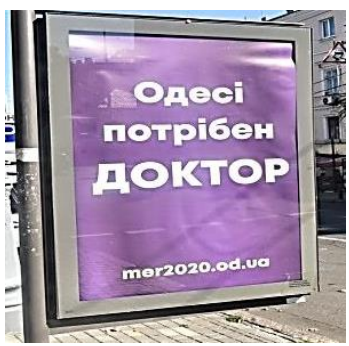


Staging is a mandatory requirement in the implementation of this strategy. Firstly, a political poster is presented, where the verbal part has a pronoun or noun without reference to a specific person. After some time, closer to the election, the following political posters appear, where surname and name of the politician are given instead of the semantically empty component.

8. Parody strategy involves the use of linguosemiotics of opponents to level their image: negative information is presented in political posters, which at the level of image and text are visually similar to the original political advertisements of competitors.

Thus, the adverse publicity political poster against Yulia Tymoshenko followed the stylistics of visual elements: national colours in the design - yellow and blue, the use of fonts identical to the original text on Yulia Tymoshenko's political posters, the image of a politician. However, an iconic element was chosen - a photograph - which illustrates the actualization of a humiliating comment - humiliation on the basis of age: The last chance for grandma. In this way, the political poster broadcasts the idea that Yulia Tymoshenko is an old politician who is once again running for president.

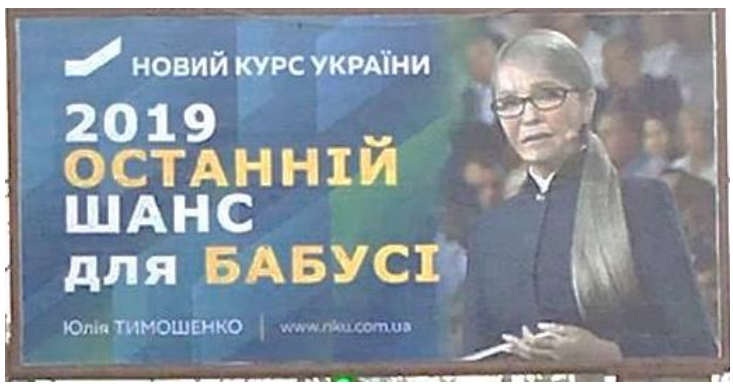

This strategy was also used in the adverse publicity of "The Opposition Platform for Life": following the linguosemiotics of the party's political posters, opponents developed a series of fake political posters.

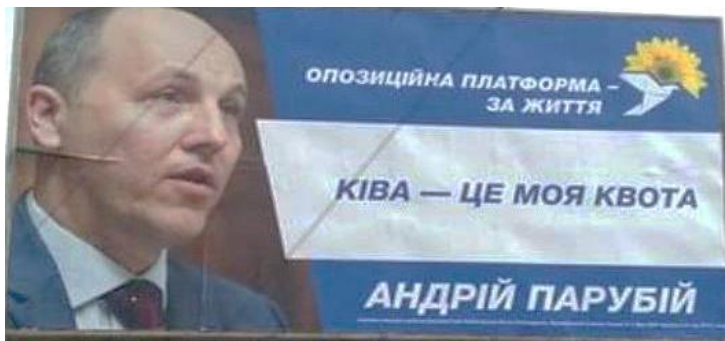


The above political poster contains a fake quote by A. Parubiy, an ideological opponent of "The Opposition Platform for Life" party, which demonstrates the falsity of his party's ideology.

Thus, the main communicative strategies of influencing the addressees in political posters are propaganda, argumentative, confrontational, dialogic, intertextual, intriguing, parody and intimidation strategies.

\section{CONCLUSIONS}

One of the types of political discourse is the pre-election discourse, within which the genre of political poster functions. A political poster is a genre expression of a pre-election discourse that contains a prominent (usually in colour) image with a short text (usually on a large sheet of paper), made for propaganda, advertising, informational or educational purposes. The main function of a political poster is to attract attention and arouse interest, to intensify perception, to direct consciousness and the will to actions in the right direction. A political poster is characterized by a guideline for persuasion, which takes into account the goals and conditions of communication.

Among political posters as polycode texts, combining elements of different sign systems - verbal, iconic, symbolic and index - there are three groups of posters: posters dominated by verbal information, posters dominated by nonverbal information and a combination of verbal and nonverbal information. The analysis of political posters in the linguopragmatic aspect showed that the main communicative strategies of influencing the addressees are propaganda, argumentative, confrontational, dialogic, intertextual, intriguing, parody and intimidation strategies. Each of the identified strategies involves the actualization of various semiotic elements of political posters.

\section{SUMMARY}

The study substantiates the relevance of interpreting a political poster as a genre of election discourse, which is a kind of political communication. The characteristic features of a political poster are determined through a combination of verbal and nonverbal components in various combinations with preference given to either the text, iconic or symbolic components. The main positions of linguists on the essence of the speech genre are outlined and the types of genres in political discourse are presented, among which a political poster is characterized taking into account its polycode specifics.

There are three groups of posters: posters with the dominance of verbal information, posters with the dominance of nonverbal information, a combination of verbal and nonverbal information. The typology of strategies of interaction with addressees in political posters of pre-election discourse is 
offered. Propaganda, argumentative, confrontational, dialogic, intertextual, intriguing, parody and intimidation strategies are described.

\section{REFERENCES}

1. Алтунян А.Г. Анализ политических текстов. Москва : Логос, 2006. $234 \mathrm{c}$.

2. Баранов А.Н. Введение в прикладную лингвистику Москва : Эдиториал УРСС, 2001. 360 c.

3. Билінська О.С. Агітаційні жанри українського політичного дискурсу: сугестивний і лінгвопрагматичний аспекти. Дис. канд. філол. наук. Одеса, 2017. 210 с.

4. Ворошилова М.Б. Политический креолизованный текст: ключи к прочтению. Екатеринбург, 2013. 194 с.

5. Гайкова О.В. Предвыборный дискурс как жанр политической коммуникации: на материале английского языка : дис. канд. филол. наук. Волгоград, 2003. 180 с.

6. Голубева Т.М. Языковая манипуляция в предвыборном дискурсе: на материале американского варианта английского языка : автореф. дис. канд. филол. наук. Нижний Новгород, 2009. 18 с.

7. Ирисханова О.К. Полимодальность в социокогнитивном освещении: семиотика плаката. Когнитивные исследования языка. 2012. № 11. С. 63-66.

8. Иссерс О.С. Коммуникативные стратегии и тактики русской речи. Москва : КомКнига, 2006. 288 с.

9. Карасик В.И. Языковой круг: личность, концепты, дискурс. Москва : Гнозис, 2004. 390 с.

10. Кондратенко Н.В., Стрій Л.І., Билінська О.С. Лінгвопрагматика політичного дискурсу: типологія мовленнєвих жанрів : монографія ; за заг. ред. Н.В. Кондратенко. Одеса : Астропринт, 2019. 236 с.

11. Магера Т.С. Текст политического плаката: лингвориторическое моделирование (на материале региональных предвыборных плакатов) : автореф. дис. канд. филол. наук. Барнаул, 2005. 22 с.

12. Павлюк Л.С. Текст і комунікація: Основи дискурсного аналізу. Львів : ПАІС, 2009. 76 с.

13. Седов К.Ф. Дискурс и личность: Эволюция коммуникативной компетенции. Москва : Лабиринт, 2004. 320 с.

14. Селіванова О.О. Сучасна лінгвістика: напрями та проблеми. Полтава : Довкілля-К, 2008. 712 с.

15. Ситар Г.В., Галюк А.В. Політичний плакат: співвідношення вербального й візуального складників. Вісник студентського наукового товариства ДонНУ імені Василя Стуса. Вип. 12. Том 2. С. 219-223. 
16. Славова Л.Л. Мовна особистість лідера у дзеркалі політичної лінгвоперсонології: США - Україна. Житомир : Вид-во ЖДУ ім. І. Франка, 2012. 360 с.

17. Халатян А.Б. Предвыборный дискурс. Политическая лингвистика. 2011. № 2. С. 180-187.

18. Чудинов А.П. Современная политическая коммуникация. Екатеринбург : Уральский гос. пед. ун-т, 2009. 292 с.

19. Шейгал Е.И. Семиотика политического дискурса. Москва : Гнозис, 2004. 326 с.

20. Янко Т.Е. Коммуникативные стратегии русской речи. Москва : Языки славянской культуры, 2001. 384 с.

Information about the author: Kondratenko N. V., Doctor of Philological Sciences, Professor, Head of the Department of Applied Linguistics Odesa I. I. Mechnikov National University 2, Dvoryanska str., Odesa, 65082, Ukraine 